\title{
Study of frequency and histopathological pattern of soft tissue tumours in tertiary care centre of Gandhinagar, Gujarat
}

\author{
Patel A. ${ }^{1}$, Patel V.N. ${ }^{2}$ \\ ${ }^{1}$ Dr. Amita Patel, Assistant Professor, Department of Pathology, GMERS Medical College, Valsad, Gujarat, India, \\ ${ }^{2}$ Dr. Vandana N. Patel, Tutor, Department of Pathology, GMERS Medical College, Gandhinagar, Gujarat, India. \\ Corresponding Author: Dr. Vandana Naranbhai Patel, C/O Dr. Vinit R. Shah, Block No. "2H”, Flat No.: 9, Shree \\ Balaji Agora Residency, Near Tapovan Circle, Sughad, Gandhinagar, Gujarat, India. E-mail:drvpatel123@gmail.com
}

\begin{abstract}
Background: Ovaries are complex intra-pelvic organs of the female reproductive system. Ovarian cancer accounts for $3 \%$ of all cancers in females and is the fifth most common cause of cancer death in women. Early menarche, late menopause, nulliparity and high socioeconomic status are associated with an increased risk for ovarian neoplasms. Histopathological diagnosis remains the mainstay to differentiate neoplastic lesions from non-neoplastic lesions. Aims and Objectives: This study aims to analyze the view of ovarian tumors with respect to clinical presentation, gross and microscopic characteristics and also to study the frequency and histopathological patterns of ovarian tumours. Materials and Methods: This study comprised of 100 cases of ovarian tumours received in the Department of Pathology, GMERS Medical College, Gandhinagar were analysed. Their gross features, microscopic findings were analysed in detail. Ovarian tumours were divided into benign and malignant categories and their further sub typing were done according to WHO Classification. Results: Out of total 100 cases, 76 were benign and 24 were malignant. Out of 100 cases, $62 \%$ were between 21-40 years of age followed by 28\% were between 41-60 years of age. Most common presenting symptom was pain in abdomen followed by lump in abdomen and heavy menstruation. Out of total 100 cases, $70 \%$ were surface epithelial tumours, 24\% were germ cell tumours and 6\% were sex cord stromal tumours. Conclusion: To conclude we recommend microscopic histopathological examination of every ovarian mass in order to assess the importance of pathological grading and staging and they must be classified correctly so that the patient can be provided with appropriate treatment and prognosis.
\end{abstract}

Keywords: Germ Cell Tumour, Histopathology, Ovarian Tumours, Sex Cord Stromal Tumour, Surface Epithelial Tumour

\section{Introduction}

Ovaries are complex intra-pelvic organs of the female reproductive system and are a common site for both benign and malignant neoplasms in all age groupsright from intrauterine period to post menopausal age group [1]. The ovary appears remarkably resistant to any form of disease except tumors [2]. The burden of ovarian tumors is next to cervical and uterine cancers in Indian females. Ovarian cancer accounts for $3 \%$ of all cancers in females and is the fifth most common cause of cancer death in women [3]. Ovarian cancers represent about $30 \%$ of all cancers of the female genital tract [4].

Indian cancer registry data project ovary as an important site of cancer comprising upto $8.7 \%$ of cancers in different parts of the country [5].

Manuscript received: $16^{\text {th }}$ December 2018

Reviewed: $27^{\text {th }}$ December 2018

Author Corrected: $2^{\text {nd }}$ January 2019

Accepted for Publication: $8^{\text {th }}$ January 2019
However, globally, ovarian cancer is the sixth most common cancer in women and the seventh most common cause of cancer death [6]. Ovary is the second most common site for female cancers next only to breast and is associated with highest mortality rate [7]. The rate of ovarian cancer increases with age. Early menarche and late menopause are significant risk factors. Surprisingly, high socioeconomic status is associated with an increased ovarian cancer risk and lower fertility [6]. Nulliparity, family history of cancerand genetic mutations are some of the risk factorsassociated with the development of ovarian neoplasmsalthough not much is clear about the risk factorsinvolved in these neoplasms as compared to othergenital tumours [8,9]. Imaging modalities like USG,CT Scan and MRI can be misleading sometimes and cytology has also its own limitations and challenges. 
Hence, histo-pathological diagnosis remains the mainstay in management and achieving an optimum treatment response [10].

There are fourmajor types of ovarian tissue, all of which can give riseto a variety of neoplasms, often combined: [11].

1. Surface, coelomic, or germinal epithelium

2. Germ cells

3. Sex cords

4. Ovarian stroma, specialized and nonspecific.

The WHO classification system of ovarian malignancies expands every year as newer entities are added each year. The classification of surface epithelial ovarian tumors is based on the following parameters: $[11,12]$

1. Cell type: serous, mucinous, endometrioid, etc.

2. Pattern of growth: cystic, solid, surface

3. Amount of fibrous stroma

4. Atypia, invasiveness and based on the biologic behavior: benign, borderline, andmalignant.

Ovarian epithelial tumours can be benign, borderline or malignant. Benign tumours can be completely cystic (cystadenomas), can have fibrous andcystic areas (cystadenofibromas) or can be predominantly fibrous (adenofibromas). The borderline and malignant tumours that have cystic component are called cystadenocarcinomas [13]. Distinction between non-neoplastic lesion and neoplastic lesion is necessary since proper treatment depends on the histologic abnormality. Different subtypes of ovarian tumors differ with respect to risk factors, precursor lesions, pattern of spread and natural history and response to treatment. Cumulatively, they are different diseases which have a common manifestation of ovarian mass. With progress toward subtype-specific treatment of ovarian carcinoma, accurate, reproducible histopathological diagnosis of these subtypes by pathologists is increasingly important [14].

Identification of various histologic patterns is important in the diagnosis and prognosis. The invasive epithelial ovarian cancers show a peak incidence between 5 th to 6th decades. In the postmenopausal women, about 30\% of ovarian tumors are malignant [15].

One of the most important clinical features is the age of the patient. The sex cord stromal tumors are almost always confined to single ovary and many metastatic tumours are bilateral. Most benign tumours of epithelial category are cystic. The presence of solid and papillary projections are important clues to likely malignancy [16].
Original Research Article

\section{Aims and Objectives}

This study aims to analyze the view of ovarian tumors with respect to clinical presentation, gross and microscopic characteristics and also to study the frequency and histopathological patterns of ovarian tumours.

\section{Materials and Methods}

Study Design: The present study was carried out at histopathology section of pathology department of GMERS Medical College and General Hospital, Gandhinagar, a tertiary care centre in Gandhinagar district of Gujarat state, India during the period of April 2014 to March 2018.

\section{Type of study: Retrospective}

Data collection procedure: In present study, we analysed all 100 cases which received for histopathology examination under the diagnosis of ovarian tumours from gynecology and surgical department.

Inclusion criteria: The specimens like Ovarian Cystectomy, Total Abdominal Hysterectomy with Bilateral salpingo oophorectomy, Salpingo oophorectomy, Oophorectomy specimens were included in this study.

Exclusion criteria: All the cervical tumors, uterine tumorsand any known already diagnosed tumours were excluded from the study.

All relevant clinical and radiological details were collected from patients. Each formalin fixed specimens received surgical specimen in Histopathology Section were examined grossly for its size, shape, weight, consistency and appearance.

Tissue cut surface was also examined for the presence of hemorrhage, necrosis and cystic spaces etc. Presence or absence of any gross involvement of adjacent structure along with depth of the tumor was also noted.

All these specimens were dissected by grossing followed by fixation, dehydration, clearing and impregnation in a automatic tissue processor.

Paraffin blocks were made and sections were cut at 3 to 5 micron thickness and haematoxylin and eosin stain was done. The findings were noted and interpreted according to the WHO classification- 2014 fourth edition [17]. 


\section{Results}

\section{Original Research Article}

Table-1: Distribution of cases as per chief complaints

\begin{tabular}{|l|c|c|c|}
\hline \multicolumn{1}{|c|}{ Chief Complaint } & Benign & Malignant & Total \\
\hline Asymptomatic & 03 & 01 & 04 \\
\hline Pain in Abdomen & 44 & 10 & 54 \\
\hline Lump in Abdomen & 19 & 07 & 26 \\
\hline Heavy Menstruation & 06 & 02 & 08 \\
\hline Others Total & 04 & 04 & 08 \\
\hline \multicolumn{1}{|c|}{ T6 } & $\mathbf{2 4}$ & $\mathbf{1 0 0}$ \\
\hline
\end{tabular}

Out of total 100 cases, 76 were benign and 24 were malignant. Most common presenting symptom was pain in abdomen $(54 \%)$ cases followed by lump in abdomen (26\%) and heavy menstruation ( $8 \%)$.

Table-2: Distribution of cases as per types of ovarian tumours

\begin{tabular}{|l|c|c|c|}
\hline \multicolumn{1}{|c|}{ Classes of Tumour } & Benign & Malignant & Total \\
\hline Surface Epithelial Tumour & 54 & 16 & 70 \\
\hline Germ Cell Tumour & 18 & 06 & 24 \\
\hline Sex Cord Stromal Tumour & 04 & 02 & 06 \\
\hline Metastatic Tumour & - & - & - \\
\hline \multicolumn{1}{|c|}{ Total } & $\mathbf{7 6}$ & $\mathbf{2 4}$ & $\mathbf{1 0 0}$ \\
\hline
\end{tabular}

Out of total 100 cases, $70 \%$ were surface epithelial tumours, $24 \%$ were germ cell tumours and $6 \%$ were sex cord stromal tumours. No any cases of metastatic tumour was identified.

Table-3: Frequency of different classes of tumours in different age groups

\begin{tabular}{|l|c|c|c|c|c|}
\hline \multicolumn{1}{|c|}{ Classes of Tumour } & $\mathbf{2 0}$ & $\mathbf{2 1 - 4 0}$ & $\mathbf{4 1 - 6 0}$ & $>\mathbf{6 0}$ & Total \\
\hline Surface Epithelial Tumour & 03 & 45 & 21 & 01 & 70 \\
\hline Germ Cell Tumour & 06 & 14 & 04 & - & 24 \\
\hline Sex Cord Stromal Tumour & - & 03 & 03 & - & 06 \\
\hline Metastatic Tumour & - & - & - & - & - \\
\hline \multicolumn{1}{|c|}{ Total } & $\mathbf{0 9}$ & $\mathbf{6 2}$ & $\mathbf{2 8}$ & $\mathbf{0 1}$ & $\mathbf{1 0 0}$ \\
\hline
\end{tabular}

Out of 100 cases, $62 \%$ were between $21-40$ years of age followed by $28 \%$ were between $41-60$ years of age, $9 \%$ were below 20 years and $1 \%$ was above 60 years.

Table-4: Frequency of benign tumours in different age groups

\begin{tabular}{|l|c|c|c|c|c|}
\hline \multicolumn{1}{|c|}{ Diagnosis } & $\mathbf{2 0}$ & $\mathbf{2 1 - 4 0}$ & $\mathbf{4 1 - 6 0}$ & $>\mathbf{6 0}$ & Total \\
\hline Serous Cystadenoma & 02 & 19 & 08 & 03 & $32(42.1 \%)$ \\
\hline Mucinous Cystadenoma & 02 & 10 & 07 & 02 & $21(27.6 \%)$ \\
\hline Mature Cystic Teratoma & 01 & 07 & 04 & 01 & $13(17.1 \%)$ \\
\hline Serous Cystadenofibroma & - & 04 & 04 & - & $08(10.5 \%)$ \\
\hline Fibroma & - & 01 & 01 & - & $02(2.6 \%)$ \\
\hline \multicolumn{1}{c|}{ Total } & $\mathbf{0 5}(\mathbf{6 . 6 \% )}$ & $\mathbf{4 1 ( 5 3 . 9 \% )}$ & $\mathbf{2 4} \mathbf{( 3 1 . 6 \% )}$ & $\mathbf{0 6}(\mathbf{7 . 9 \% )}$ & $\mathbf{7 6}(\mathbf{1 0 0} \%)$ \\
\hline
\end{tabular}

Out of total 76 benign neoplastic cases, 41 cases (53.9\%) were between $21-40$ years of age followed by 24 cases (31.6\%) were between 41-60 years of age, 6 cases $(7.9 \%)$ were above 60 years and 5 cases $(6.6 \%)$ were below 20 years. Out of total 76 benign neoplastic cases, 32 cases (42.1\%) were of serous cystadenoma followed by 21 cases $(27.6 \%)$ were of mucinous cystadenoma, 13 cases $(17.1 \%)$ were of mature cystic teratoma, 8 cases $(10.5 \%)$ were of serous cystadenofibroma and 2 cases $(2.6 \%)$ were of fibroma. 


\section{Original Research Article}

Table-5: Frequency of individual malignant tumours in different age groups

\begin{tabular}{|l|c|c|c|c|c|}
\hline Diagnosis & $\mathbf{2 0}$ & $\mathbf{2 1 - 4 0}$ & $\mathbf{4 1 - 6 0}$ & $>\mathbf{6 0}$ & Total \\
\hline Serous Carcinoma & - & 01 & 03 & 01 & $05(20.8 \%)$ \\
\hline Mucinous Carcinoma & - & 01 & 02 & 02 & $05(20.8 \%)$ \\
\hline Yolk Sac Tumour & - & 02 & - & - & $02(8.3 \%)$ \\
\hline Dysgerminoma & 01 & 01 & - & - & $02(8.3 \%)$ \\
\hline Endometrioid Carcinoma & - & - & 02 & 01 & $03(12.5 \%)$ \\
\hline Granulosa Cell Tumour & - & 04 & - & - & $04(16.7 \%)$ \\
\hline Clear Cell Carcinoma & - & - & 02 & - & $02(8.3 \%)$ \\
\hline Transitional Cell Carcinoma & - & - & 01 & - & $01(4.2 \%)$ \\
\hline Total & $\mathbf{0 1}(\mathbf{4 . 2 \% )}$ & $\mathbf{0 9 ( 3 7 . 5 \% )}$ & $\mathbf{1 0 ( 4 1 . 7 \% )}$ & $\mathbf{0 4}(\mathbf{1 6 . 7 \% )}$ & $\mathbf{2 4}(\mathbf{1 0 0} \%)$ \\
\hline
\end{tabular}

Out of total 24 malignant neoplastic cases, 10 cases (41.7\%) were between 41-60 years of age followed by 9 cases (37.5\%) were between 21-40 years of age, 4 cases (16.7\%) were above 60 years and 1 case (4.2\%) was below 20 years.Out of total 24 malignant neoplastic cases, 5 cases $(20.8 \%)$ were of serous carcinoma and mucinous carcinoma each followed by 4 cases $(16.7 \%)$ were of granulose cell tumour, 3 cases $(12.5 \%)$ were of endometrioid carcinoma, 2 cases $(8.3 \%)$ were of yolk sac tumour, dysgerminoma and clear cell carcinoma each and 1 case $(4.2 \%)$ was of transitional cell carcinoma.

\section{Discussion}

In the present study, 100 ovarian tumours were analyzed, out of which 76 cases $(76.0 \%)$ cases were benign and 24 cases $(24.0 \%)$ were malignant. This is in concordance with the study conducted by Abdullah et al and Neethu GV et al where $78.0 \%$ and $70.3 \%$ of the ovarian tumours in their study were benign and $22 \%$ and $29.7 \%$ were malignant respectively $[18,19]$. While in study of Jha $\mathrm{R}$ et al and Ranjana Hawaldar et al benign cases were $84 \%$ and $91.5 \%$ respectively [20,21].

The most common neoplasm diagnosed in the present study was the surface epithelial tumours which constituted $70 \%$. This was comparable to study done by Neethu CV et al, Ranjana Hawaldar et al and Makwana $\mathrm{HH}$ et al where the incidence of the surface epithelial tumours was $74.4 \%, 69.7 \%$ and $65.7 \%$. No borderline tumour was found in our study $[19,21,22]$.

Next most common ovarian neoplasm were the germ cell tumours, which constituted $24 \%$. This was closely comparable with study conducted by Ranjana Hawaldar et al and Makwana $\mathrm{HH}$ et al where the incidence of the germ cell tumours was $24.4 \%$ and $22.86 \%$ respectively $[21,22]$. The least common ovarian neoplasm diagnosed in our study was sex cord stromal tumours whose incidence was only $6 \%$ which was quite similar to study of Neethu CV et al where the incidence was 7.4\% [19].

In the present study, serous tumours were found to be more common among the surface epithelial tumours. Studies on ovarian tumours carried out by Neethu CV et al, Nalini $G$ et al and Maheshwari et al have also reported similar results where the serous cystadenoma were the most common [19,23,24].
Among the malignant surface epithelial tumours, high grade serous carcinoma was the most common tumour diagnosed in our study group. This does not correlate with the study conducted by Yasmeen $\mathrm{S}$ et al where endometroid carcinoma was found to be more prevalent [25]. Germ cell tumours (GCT) were the second most common tumours $(24 \%)$ to be diagnosed in the present study. Incidence of mature cystic teratomas among the benign germ cell tumours was highest. Similar findings were obtained by Ashraf A et al [26].

Among the sex cord stromal tumours that were diagnosed in our study, granulosa cell tumour was the most common. Similar incidences were obtained in other studies like the studies by Makwana $\mathrm{HH}$ et al and Ashraf A et al [22,26].

The age range of patient was from 12 to 69 years.Maximum number of benign cases were seen in the age groupof 21-40 years followed by 41-60 years age group. Maximum number of malignant cases were seen in the age groupof 41-60 years followed by 21-40 years age group. Least number of cases were seen in age less than 20 years and above 60 years of age.

Sheikh $\mathrm{S}$ et al in her study found maximum cases in 2140 years of age group similar to that seen in our study [27]. Peak age for benign tumours were seen in 3rd to 4th decade, which is similar to study done by Dhakal $\mathrm{R}$ et al and Sawant A et al $[28,29]$.

In study of Sawant A et al, peak age of malignant tumours also found in patients of 41-60 years of age as seen in our study [29]. 
Most common clinical presentation was pain abdomen (54\%) and abdominopelvic lump (26\%) which was similar to study done by Bodhal VK etal. Other clinical presentation were heavy menstruation (8\%) and incidental finding (4\%) [30].

\section{Conclusion}

Ovary is a common site of neoplasia in the femalegenital tract which constitute a major burden amongwomen presenting to the gynecological OPD and usually present with a variety of clinicomorphological and histological features. However, benign tumours are far more common thantheir malignant counterparts with surface epithelialtumours being the commonest followed by germ celltumours, majority presenting in 21-40 years age group.

Toconclude we recommend microscopic histopathological examination of every ovarian mass in order to assess the importance of pathologicalgrading and staging and theymust be classified correctly so that the patientcan be provided with appropriate treatment andprognosis.

What this study adds to existing knowledge: This is important to know the different variety of pattern of ovarian tumours in Gandhinagar district.

Author contribution: First author Dr. Amita Patel has prepared the study design and drafted manuscript in presentable manner for publication. Second and corresponding author Dr. Vandana Patel has collected all data and done study in his own institute.

Findings: Nil; Conflict of Interest: None initiated Permission from IRB: Yes

\section{References}

1. Young RH. The ovary. In: Sternberg S. Diagnostic Surgical Pathology. 17th Ed. New York: Raven Press; 1994. P. 2195.

2. Birare SD, Dale AR. Clinicopathological study of ovarian tumours: a 5 year study. Ind J Pathol Oncol, 2018;5(3):360-365. DOI: 10.18231/2394-6792. 2018. 0070

3. Montag A, Kumar V. The female genital system and breast. Robbins Basic Pathology. 9th Ed. Philadelphia: Saunders Elsevier. 2014:991-1042.

4. Mankar DV, Jain GK. Histopathological Profile of Ovarian tumours. A twelve year experience. Muller J Med Sci Res. 2015;6(2):107-11. DOI: 10.4103/09759727.160675

\section{Original Research Article}

5. Murthy NS, Shalini S, Suman G, et al. Changing trends in incidence of ovarian cancer - the Indian scenario. Asian Pac J Cancer Prev. 2009;10(6):1025-30.

6. Kurman RJ, Ellenson LH, Ronnett BM, Blaustein's pathology of female genital tract, 6th Ed., New York: Springer:2011.p.680-2.

7. JaunRosai, "Rosai and Ackerman's Surgical Pathology, " 9th Ed., New Delhi, Elsevier 2004.

8. Aziz S, Kuperstein G, Rosen B, et al. A genetic epidemiological study of carcinoma of the fallopian tube. Gynecol Oncol. 2001 Mar;80 (3):341-5.

9. Narod SA, Boyd J. Current understanding of the epidemiology and clinical implications of BRCA1 and BRCA2 mutations for ovarian cancer. CurrOpinObstet Gynecol. 2002 Feb;14 (1):19-26.

10. Novak ER, and Woodruff JD. In: Novak's Gyneacologic and Obstetric pathology.

11. Rosai J. Rosai and Ackerman's Surgical Pathology. Tenth Ed., New York: Mosby Elsevior;2011.p.1562-3.

12. Sharma I, Sharma U, Dutta UC. Pathology of Ovarian Tumours-A Hospital based study. International Journal of Medical Science and Clinical Invention. $2014 ; 1(6)$ : 284-6.

13. Ellenson LH, Pirog EC. Robbins and Cotran pathologic basis of disease. 9th Ed. Philadelphia (USA), Elsevior and Saunders Press; 2014. Chapter 22, The Female Genital Tract; p.991-1042.

14. Gilks CB, Prat J. Ovarian carcinoma pathology and genetics: recent advances. Hum Pathol. 2009 Sep; 40 (9): 1213-23. doi: 10.1016/j.humpath.2009. 04.017. Epub 2009 Jun 24.

15. S.N.Kanthikar. "Clinico-Histopathological Analysis of Neoplastic and Non-Neoplastic Lesions of the Ovary: A year Prospective Study in Dhule, North Maharashtra, India. J Clin Diagn Res. 2014;8 (8): 04-07. DOI: 10.7860 / JCDR/2014/8911.4709

16. Mondal $\mathrm{SK}^{1}$, Banyopadhyay $\mathrm{R}, \mathrm{Nag} \mathrm{DR}$, et al. Histologic pattern, bilaterality and clinical evaluation of 957 ovarian neoplasms: a 10-year study in a tertiary hospital of eastern India. J Cancer Res Ther. 2011 OctDec;7(4):433-7. doi: 10.4103/0973-1482.92011.

17. Robert J. Kurman, Maria Luisa Carcangiu, C. Simon Herrington, Robert H. Young, (Eds.): WHO Classification of Tumours of Female Reproductive Organs 4th Edition IARC Lyon. 2014.p.12-13. 
18. Abdullah LS ${ }^{1}$, Bondagji NS. et al. Histopathological pattern of ovarian neoplasms and their age distribution in the western region of Saudi Arabia. Saudi Med J. 2012 Jan;33(1):61-5.

19. Neethu GV, Divya P, Preethi CR, Rajashekar KS, Soumya BM. Histopathological study of ovarian tumours. Ind J Pathol Oncol, 2018;5 (1): 25-8. DOI: 10. 1823/2394-6792.2018.0005.

20. Jha R, Karki S. Histological pattern of ovarian tumors and their age distribution. Nepal Med Coll J. 2008 Jun;10(2):81-5.

21. Ranjana Hawaldar, SadhnaSodani, Ekta Patidar. Histopathological spectrum of ovarian tumours - A two years retrospective study. Ind J Pathol Oncol, 2017;4 (3):450-453. DOI: 10.18231/2394-6792.2017.0097

22. Makwana HH, Maru AM, Lakum NR, Agnihotri AS, Trivedi NJ, Joshi JR. The relative frequency and histopathological pattern of ovarian masses - 11 year study at tertiary care centre. Ind J Med Sci Public Health, 2014;3 (1): 81-4. DOI: 10.5455/ ijmsph. 2013. 061020132

23. Gupta N, Bisht D, Agarwal AK, et al. Retrospective and prospective study of ovarian tumours and tumourlike lesions. Indian J PatholMicrobiol. 2007 Jul;50 (3): 525-7.

\section{Original Research Article}

24. Maheshwari V, Tyagi SP, Saxena K, et al. Surface epithelial tumours of the ovary. Indian $\mathrm{J}$ Pathol Microbiol. 1994 Jan;37(1):75-85.

25. Yasmeen S, Yasmeen A. Frequency of benign and malignant ovarian tumours in a tertiary care hospital. J Postgrad Med Inst 2006;20(4):393-7.

26. Ashraf A, Shaikh AS, Ishfaq A, Akram A, Kamal F, Ahmed N. The relative frequency and histopathological patterns of ovarian masses. Biomed 2012;28(1):98-102.

27. Sheikh S, Bashir H, Farooq S, Beigh A, Manzoor F, Reshi R. Histopathological spectrum of ovarian tumours from a referral hospital in Kashmir valley, Jammu and Kashmir, India. Intl J Res Med Sci, 2017;5 (5):2110-4. DOI: 10.18203/2320-6012.ijrms20171852

28. Dhakal R, Makaju R, Bastakoti R. Clinicomorphological spectrum of ovarian cystic lesions. Kathmandu Univ Med J. 2016;14(53):13-6. PMID: 27892434

29. Sawant A, Mahajan S. Histopathological study of ovarian lesions at a tertiary health care institute. MVP J Med Sco, 2017;4(1):26-9. DOI: 10.18311/ mvpjms/0/ $\mathrm{v} 0 / \mathrm{i} 0 / 724$

30. Bodal VK, Jindal T, Bal MS, Bhaga R, Kaur S, Mall N, Goyal P. A clinicopathological study of ovarian lesions. RRJMHS 2014;3(1):50-6.

\section{How to cite this article?}

Patel A., Patel V.N., Study of frequency and histopathological pattern of soft tissue tumours in tertiary care centre of Gandhinagar, Gujarat. Trop J Path Micro 2019;5(1):20-25.doi:10.17511/jopm.2019.i01.04. 